\title{
Corporate Governance Structure and Its Relationship with Audit Fee-Evidence from Malaysian Public Listed Companies
}

\author{
Azrul Ihsan Husnin ${ }^{1}$, Anuar Nawawi ${ }^{1} \&$ Ahmad Saiful Azlin Puteh Salin ${ }^{2}$ \\ ${ }^{1}$ School of Accounting, Universiti Teknologi MARA Shah Alam, Selangor, Malaysia \\ ${ }^{2}$ School of Accounting, Universiti Teknologi MARA Perak, Malaysia \\ Correspondence: Ahmad Saiful Azlin Puteh Salin, School of Accounting, Universiti Teknologi MARA Perak, \\ Bandar Seri Iskandar, 32610 Seri Iskandar, Perak, Malaysia. Tel: 60-5374-2544. E-mail: \\ ahmad577@perak.uitm.edu.my; saifulazlin@yahoo.com
}

Received: August 15, 2013 Accepted: September 3, 2013 Online Published: October 29, 2013

doi:10.5539/ass.v9n15p305 URL: http://dx.doi.org/ass.v9n15p305

\begin{abstract}
This study investigates the relationship between the firms' internal corporate governance mechanisms with audit fee in Malaysia. Different to other study conducted previously, this study also looks at the objectives of the study from the perspective of the newly introduced Malaysian Code of Corporate Governance (MCCG 2007) which was introduced in October 2007. The data consisted of a sample of 300 companies in Bursa Malaysia from pre-MCCG 2007 (year 2006) to post-MCCG 2007 (year 2008) (900 firm-years). Ordinary least square (OLS) regression method was utilized to analyze audit fee hypotheses developed. It was found that in general MCCG 2007 influenced the determinants of audit fee through the restructuring of corporate governance monitoring tools such as audit committee and internal audit function. Future research is recommended to study the impact of MCCG 2007 in a more specific manner such as to incorporate qualitative data and use longer time frame.
\end{abstract}

Keywords: corporate governance, audit fee, code of corporate governance, Malaysia

\section{Introduction}

\subsection{Background of the Study}

Malaysia is one of the countries that was heavily affected by the East Asian financial crisis in 1997. Since the aftermath of the 1997 East Asian financial crisis, Asian Tigers including Hong Kong, Singapore and Malaysia (Sawicki, 2009) have taken a leap to improve their Corporate Governance (CG) as it was identified that a weaker CG escalated the crisis (Mitton, 2002). In 2007, the new revised Malaysian Code of Corporate Governance (MCCG) was issued to replace the previous MCCG 2001 and several improvements have been proposed to strengthen the entity's CG especially for those companies which are publicly listed in Bursa Malaysia.

For example, MCCG 2007 focused primarily in improving the effectiveness of the Audit Committee (AC) through improving its composition and independence. Thus, it is expected that the audit structure of the company will improved and consequently lower various risks of the company. Due to this, will there be any changes on the audit fee paid for the audit work performed by the auditor? These interesting questions will be attempted by this study.

There are few study conducted on the audit fee in Malaysia such as Puan, Pamela \& Peter (2006), Mark, Balachandran \& Abdul (2007) and Effiezal Aswadi, Mazlinah, Kieran \&Hasnah (2009). These studies however only focused on the impact of the early implementation of MCCG in 2001. Contrary, this paper will focus more on the impact of the Second MCCG revision in 2007.

Thus, an objective of this study is to investigate the relationship between the firm's internal CG mechanisms with the audit fee charged in Malaysia. The internal CG that become the interest of this study includes ownership concentration, audit committee's composition and operation, chief executive officer's duality, firm's financial position, firm's ownership dominance, political influence, share price and family-controlled. This study further analyzes the impact of the MCCG 2007 on those relationships at three different occasions: prior, post, and during the transitional period to MCCG 2007. The significant of this study is it envisaged to enrich the knowledge of the Malaysian CG as well as give more up-to-date scenario on the audit fee in Malaysia and covers the impact of the recent amendments to the MCCG (MCCG, 2007). 


\subsection{Literature Review and Hypotheses Development}

The research on audit fee worldwide and especially in Malaysia is quite rampant based on past literature. Audit fee is also among the proxies that have been used by researchers to identify audit quality as conducted by Effiezal Aswadi et al. (2009); Mark, Balachandran \& Abdul (2007); and Puan et al. (2006). Even, when higher (lower) fees disclosed, investors percieved that aduit quality and auditor effort is high (low), respectively (Beck et al., 2013). Recent evidence however finds that fee premium does not necessarily related to audit quality (Simon, 2011). Krauß et al. (2013) and Wahab and Zain (2013) suggest that fee discount for initial audit engagements do not make any differences in audit quality and auditor independence, but more on the response to the competitive market conditions. Interestingly, Asthana and Boone (2012) argued that abnormal audit fees increased can be a warning signal of lower audit quality due to increasing in client bargaining power.

It is worth to mention that research regarding audit fee and internal CG structure in Malaysia has heavily been done using the data from 1999 to 2003 due to the introduction of the first MCCG in 2001. Among the determinants of audit fee are corporate size (Waresul \& Moizer, 1996; Sandra \& Patrick, 1993; Kamal \& Rana, 2008), status of the audit firm (big 4 or non-big 4) (Waresul \& Moizer, 1996; Kamal \& Rana, 2008), industry type (Mohd \& Takiah, 1993; Kamal \& Rana, 2008; Leventis, Hassan \& Dedoulis, 2013; Casterella, Desir \& Irwin, 2013), degree of corporate complexity (Sandra \& Patrick, 1993; Kamal \& Rana, 2008; Sundgren \& Svanstrom, 2013), perceived risk (Sandra \& Patrick, 1993; Mark et al., 2007; Kamal \& Rana, 2008; Aswadi et al., 2009; Kim \& Fukukawa, 2012), ownership concentration (Aswadi et al., 2009), type of equity ownership (Badertscher et al., 2013) and audit delay (Sandra \& Patrick, 1993; Coster, Dahl \& Jenson, 2013). In addition, Taylor \& Simon (1999) found that higher audit fee is associated to litigation propensity, higher level of disclosure (and stringent regulation while Stanley (2011) finds that audit fees reflects future changes in client earnings. Substantial regulatory changes such as introduction of Sarbanese-Oxly Act also lead to higher audit fees due to increasing compliance costs (Ebrahim, 2010).

The amount of audit fee also reflects the perceived inherent risk of the auditor on the firm (Mark et al., 2007; Puan et al., 2006; Effiezal Aswadi et al., 2009). Prior research found that the size of an AC has a significant relationship with monitoring effectiveness (DeAngelo, 1981; Leuz \& Verrecchia, 2000; Al-Ajmi, 2008). The bigger the size of the $\mathrm{AC}$, the stronger the internal CG mechanism such as internal audit functions is expected and vice versa. Stronger internal audit functions contribute to lower external audit fees (Prawitt, Sharp \& Wood, 2011). In addition, the existence of a higher proportion of independent and non-executive directors on the AC, the large number of members and the frequent meetings improve the monitoring effectiveness on the management's activities. For example, after the introduction of SOX, company with the present audit committee will dismiss low quality auditor and hire high quality auditor (Abbot, Gunny \& Zhang, 2013), so they need to dedicate more resources. Hence, information asymmetry and perceived riskiness may reduce. Thus, the following hypothesis is derived:

Hypothesis 1: Ceteris paribus, a firm with higher proportion of independent and non-executive directors on audit committee, has more members and meet more frequently has a negative relationship with audit fee.

Hypothesis 1a: Ceteris paribus, frequent audit committee meetings has a negative relationship with audit fee.

Hypothesis 1b: Ceteris paribus, higher proportion of independent directors in audit committee has a negative relationship with audit fee.

Hypothesis 1c: Ceteris paribus, a large number of members in audit committee has a negative relationship with audit fee.

Hypothesis 1d: Ceteris paribus, higher proportion of non-executive directors in audit committee has a negative relationship with audit fee.

There are a number of researches worldwide mentioning the effects of ownership concentration on the corporate governance (La, Florencio \& Andrei, 1999; Haiyan, Ahsan \& Clive, 2009). Companies with higher concentrated ownership had more incentive to expropriate the minority's wealth (Cheung, Stouraitis \& Wong, 2005; Burkart $\&$ Panunzi, 2006). The holder will divert the wealth of the company for the private benefits such as determine their own remuneration and perks, make decision that only benefited majority shareholders and have tendency to override internal control of the company. Since larger ownership concentration creates more incentive to expropriate minority's wealth, so there is a higher perceived riskiness for a larger percentage of total shares held by the largest owner. Thus, the following hypothesis is derived:

Hypothesis 2: Ceteris paribus, the higher the percentage of total shares held by the largest owner, the higher the audit fee. 
CEO duality allows for little transparency via a lack of monitoring on the CEO's actions as he/she has a significant influence on BOD decision (Lin \& Liu, 2009; Kim et al., 2009). It can be said that by having duality on the CEO post, the CEO has a greater incentive to pursue his/her private interest without being challenged thus, reflecting bad CG. In addition, when there is CEO duality in a firm, the inherent risk for the financial statement to be manipulated is higher due to the higher concentration of power. Hiring a high quality auditor may cause his/her private intention be limited or even jeopardized. So, there is less incentive for the CEO in this case to employ a high quality auditor. Thus, the following hypothesis is derived:

Hypothesis 3: Ceteris paribus, there is a positive relationship between the existence of CEO duality and audit fee.

Lin \& Liu (2009) argued that the incentive for opaqueness gains among the listed companies in China induced by the bearish state of China's economy between 2001-2004.Relating this situation to the companies in Malaysia, most of the severed and financially-troubled firms are classified as Practice Note 17 (PN17). In order to further harmonize with the Malaysian market environment, loss-making companies are also considered to have high probability to face financial distress. The perceived inherent riskiness is higher for the company with a financially troubled condition. This is with the reason that there might be an existence of a stronger incentive to alter financial report with the intention to ensure the unfavourable condition could be reflected otherwise. Thus the following hypothesis is derived:

Hypothesis 4: Ceteris paribus, there is a positive relationship between the firm categorized as PN17 and a loss-making with audit fee.

Effiezal et al. (2009) suggested both the auditor and the ethnicity background of the audit's clients are important to determine the audit fee in Malaysia. They found there is a significant relationship between the amount of audit fee with institutional ownership. In particular, firms with institutional ownership demand a quality audit thus causing a higher audit fee. The concept of audit fee reflecting the perceived riskiness by the auditors is in line with the concept used by Mark et al. (2007). In addition, Kane \& Velury (2004) argued that the institution owner perceived that larger audit firms in average provided higher audit quality. So, the larger the institutional ownership the more likely larger audit firms will be chosen. They further suggested that whenever both the auditor and audit clients who dominate the company are of the same ethnicity, there is a possibility for the audit fee to be lower due to favorable behavior. The same results were also supported by Puan et al. (2006) in addition to the etchnicity ownership of the company. According to these authors there is a strong negative relationship between external audit fee and Bumiputera owned firms due to the favorable CG structure among bumiputra-owned firms. Thus the following hypothesis is derived:

Hypothesis 5: There is a relationship between the ownership dominance of the firm with audit fee.

Based on the previous literature, it is posited that there will be an impact on the amount of audit fee imposed and the selection of auditors on politically-connected firms. Politically-owned firms are perceived to bear higher inherent risk by auditors due to the higher possibility of business failure, and are more likely to misstate their financial information to avoid covenant violation (Effiezal et al., 2009). A higher inherent risk is reflected by higher audit fee charged upon the firm. Politically-connected firms tend to incur higher audit fee since auditors perceive them to be riskier. Cohen and Leventis (2013) also suggest that highly politicized environment is proxy for reputation risk by auditor and hence, adjust the audit fees accordingly. Thus the following hypothesis is derived:

Hypothesis 6: Ceteris paribus, there is a relationship between politically-connected firms and higher audit fee.

Higher audit fee may signal shareholders about the risk level of their investments. When assessing the risk of the company, some auditor may doing short-cut by increasing audit fees as an insurance for future litigation cost instead of increasing their effort and tasks in performing their job (Kim \& Fukukawa, 2012). This type of company, whereas the inherent risks are higher may be reflected on the shareholder's discount of the share price of the company. Thus the following hypothesis is derived:

Hypothesis 7: Ceteris paribus, there is a relationship between audit fee and share price.

It is posited that based on the initial expectation of the CG practice by family-controlled firms, these firms may carry a substantial inherent risk. Family controlled firms is known has weaker governance, appointed their family members that sit in the board and top management of the company and like to override existing internal controls. Because of that, it is posited that the auditors may charge a higher audit fee for such risks. Thus the following hypothesis is derived:

Hypothesis 8: Ceteris paribus, there is a positive relationship between family-controlled firms and audit fee. 


\section{Method}

\subsection{Sample selections}

Most of the financial data are collected from the financial database such as DataStream and Thomson One banker for all PLCs in Bursa Malaysia excluding banks and other related financial institutions for the period between 2006 and 2008. Content analysis will be utilized to extract other data which are not available on both databases through either individual company's annual report or company's official corporate website.

The year 2007 is chosen as the cut-off year since 2007 is the latest year in which the Malaysian CG code was revised by the Malaysian SC. The year 2006 is considered as pre-MCCG 2007 year while the year 2008 is considered as post-MCCG 2007 year. By doing so, perhaps, it might be possible to see and assess the key changes in the determinants of the dependent variables among the pre, post and during the introduction of the new MCCG 2007.

The population of this study includes all the companies listed on the Bursa Malaysia main market and second market from 2006 to 2008. Since this study employs convenient sampling based on the industries, the companies are selected without prejudice regardless of its financial year end and board listed. All banks and financial institutional firms are primarily removed from the population due to the differences in the laws and regulations. The industry classifications are derived from Worldscope which gives thorough and richer industry classifications. Table 1 shows the final samples consisting of 900 firm years (300 firms for each year from 2006 to 2008). 2007 is chosen as the cut-off year since 2007 was the year in which the new MCCG 2007 was introduced to the market.

Table 1. Sample selection according to year

\begin{tabular}{lc}
\hline Years & Frequency \\
\hline Year 2006 (Pre MCCG 2007) & 300 \\
Year 2007 (Transition to MCCG 2007) & 300 \\
Year 2008 (Post MCCG 2007) & 300 \\
Final Sample (Firm Years) & $\mathbf{9 0 0}$ \\
\hline
\end{tabular}

\subsection{Regression Model}

The model used by Effiezal Aswadi et al. (2009) and Mary et al. (2005) are modified in this study to test the hypotheses as follows:

$$
\mathrm{Y}=\beta 0+\mathrm{b} 1 \mathrm{X} 1+\mathrm{b} 2 \mathrm{X} 2+\mathrm{b} 3 \mathrm{X} 3+\mathrm{b} 4 \mathrm{X} 4+\mathrm{b} 5 \mathrm{X} 5+\mathrm{b} 6 \mathrm{X} 6+\mathrm{b} 7 \mathrm{X} 7+\mathrm{b} 8 \mathrm{X} 8+\mathrm{b} 10 \mathrm{CV}+\varepsilon
$$

The analysis of the data is conducted by using binomial logistics, Ordinary Least Square (OLS) and multinomial logistic regression methods which are tested on developed models based on the past researches.

\subsection{Measurement of Variables}

The dependent variable of the study is an audit fee. It represent by $\mathrm{Y}$, measured based on natural log of audit fee. The independent variables of the study are audit committee composition and operations, concentrated ownership, CEO duality, company's financial position, ownership dominance, political influence, share price and family-controlled. Control variables for the study includes the company's size, growth, profitability, assets structure, financial leverage and risks 
Table 2. Measurement of variables

\begin{tabular}{|c|c|c|}
\hline Symbol & Variable & Definition \\
\hline Y & Auditor fee & A dependent variable that measure based on Natural log of audit fee \\
\hline $\mathrm{X} 1$ & $\begin{array}{lr}\text { Audit } & \text { Committee } \\
\text { composition } & \text { and } \\
\text { operation } & \end{array}$ & $\begin{array}{l}\mathrm{AC} \text { composition and operation consists of four key variables. First, the } \\
\text { frequency of } \mathrm{AC} \text { meeting during the year (X1a). Second, the proportion of } \\
\text { independent directors in } \mathrm{AC}(\mathrm{X} 1 \mathrm{~b}) \text {. Third, the number of AC members } \\
\text { (X1c). Fourth, the proportion of non-executive directors in AC (X1d) }\end{array}$ \\
\hline $\mathrm{X} 2$ & Block Shareholder & $\begin{array}{l}\text { The percentage of ownership that an individual who holds the largest } \\
\text { shares on an entity }\end{array}$ \\
\hline $\mathrm{X} 3$ & CEO duality & $\begin{array}{l}\text { A dummy variable to indicate the existence of CEO who also holds the } \\
\text { position as Board chairman in an entity }\end{array}$ \\
\hline $\mathrm{X} 4$ & Financial state & $\begin{array}{l}\text { A dummy variable to indicate whether an entity faces a financial distress } \\
\text { situation or not. Financial distress companies include those companies that } \\
\text { are listed as PN17 or those which experienced financial loss for } 3 \text { years } \\
\text { consecutively from } 2006 \text { to } 2008\end{array}$ \\
\hline $\mathrm{X} 5$ & Ownership dominance & $\begin{array}{l}\text { A variable that indicates the ownership control based on shareholders' } \\
\text { ethnic majority within a specific entity whether Chinese dominated (X5a), } \\
\text { Bumiputra dominated (X5b) or institutionally owned (X5c) }\end{array}$ \\
\hline X6 & Political influence & $\begin{array}{l}\text { A variable that indicates the strength of political influence within an entity } \\
\text { whether strong (X6a) or weak connection (X6b) }\end{array}$ \\
\hline $\mathrm{X} 7$ & Share price & An entity yearly closing share price as at $31^{\text {st }}$ December \\
\hline $\mathrm{X} 8$ & Family-controlled & $\begin{array}{l}\text { A dummy variable that indicates whether an entity is controlled by a } \\
\text { family or not }\end{array}$ \\
\hline $\mathrm{X} 10$ & Log of total assets & A control variable that indicates the size of an entity \\
\hline $\mathrm{X} 11$ & Assets turnover ratio & A control variable that indicates the growth of an entity \\
\hline $\mathrm{X} 12$ & Return on assets & A control variable that indicates the profitability of an entity \\
\hline $\mathrm{X} 13$ & $\begin{array}{l}\text { Current assets over total } \\
\text { assets }\end{array}$ & A control variable that indicates asset structure of an entity \\
\hline X14 & $\begin{array}{l}\text { Total liabilities over } \\
\text { total assets }\end{array}$ & A control variable that indicates financial leverage of an entity \\
\hline $\mathrm{X} 15$ & Beta & A control variable that indicates the risk of an entity; the higher the riskier \\
\hline
\end{tabular}

\section{Results}

\subsection{Correlation Matrix}

Table 3 of Correlation Coefficient Matrix of Dependent and Independent Variables (2006-2008) depicts the correlation coefficient matrix of the dependent and independent variables. It shows that 11 out of the 15 variables were significantly correlated with the dependence variable. The natural $\log$ of audit fee was significantly correlated to $\mathrm{AC}$ meeting frequency, $\mathrm{r}=0.25, \mathrm{p}<.01$; proportion of independent directors in $\mathrm{AC}, \mathrm{r}=0.09, \mathrm{p}<.01$; $\mathrm{AC}$ size, $\mathrm{r}=0.18, \mathrm{p}<.01$; proportion of non-executive directors in $\mathrm{AC}, \mathrm{r}=0.16, \mathrm{p}<.01$; percentage of block shareholders, $\mathrm{r}=0.08, \mathrm{P}<.05$; financial state, $\mathrm{r}=-0.17, \mathrm{p}<.01$; Chinese dominance, $\mathrm{r}=-0.34, \mathrm{p}<.01$; Institutional dominance, $\mathrm{r}=0.36, \mathrm{p}<.01$; strong political connection, $\mathrm{r}=0.42, \mathrm{p}<.01$; yearly closing share price, $\mathrm{r}=0.21, \mathrm{p}<.01$; and family-controlled firms, $r=-0.07, \mathrm{p}<.0 .1$. 
Table 3. Correlation coefficient matrix of dependent and independent variables (2006-2008)

\begin{tabular}{|c|c|c|c|c|c|c|c|c|c|c|c|}
\hline & $\mathbf{Y}$ & X1a & $\mathrm{X1b}$ & X1c & X1d & $\mathrm{X} 2$ & $\mathrm{X3}$ & $\mathrm{X4}$ & X5a & $X 5 b$ & $\mathrm{X5c}$ \\
\hline $\mathrm{Y}$ & 1.00 & & & & & & & & & & \\
\hline X1a & $0.25^{* * *}$ & 1.00 & & & & & & & & & \\
\hline $\mathrm{X} 1 \mathrm{~b}$ & $0.09 * *$ & 0.02 & 1.00 & & & & & & & & \\
\hline $\mathrm{X} 1 \mathrm{c}$ & $0.19 * * *$ & $0.08 * * *$ & $-0.19 * * *$ & 1.00 & & & & & & & \\
\hline X1d & $0.16^{* * *}$ & $0.12^{* * *}$ & $0.50 * * *$ & $-0.08 * *$ & 1.00 & & & & & & \\
\hline $\mathrm{X} 2$ & $0.08^{* *}$ & 0.02 & -0.05 & $0.22 * * *$ & 0.33 & 1.00 & & & & & \\
\hline $\mathrm{X} 3$ & -0.01 & -0.01 & 0.00 & $-0.11 * * *$ & $-0.15 * * *$ & -0.03 & 1.00 & & & & \\
\hline $\mathrm{X} 4$ & $-0.17 * * *$ & 0.04 & 0.04 & $-0.17 * * *$ & 0.03 & $-0.19 * * *$ & 0.00 & 1.00 & & & \\
\hline $\mathrm{X} 5 \mathrm{a}$ & $-0.34 * * *$ & $-0.14 * * *$ & -0.02 & $-0.20 * * *$ & $-0.20 * * *$ & $-0.12 * * *$ & $0.22 * * *$ & $-0.08 * * *$ & 1.00 & & \\
\hline $\mathrm{X} 5 \mathrm{~b}$ & 0.01 & -0.03 & 0.01 & -0.02 & 0.03 & 0.03 & 0.01 & -0.01 & $-0.34 * * *$ & 1.00 & \\
\hline $\mathrm{X} 5 \mathrm{c}$ & $0.36^{* * *}$ & $0.16^{* * *}$ & 0.01 & $0.24 * * *$ & $0.18^{* * *}$ & $0.15^{* * *}$ & $-0.25 * * *$ & $-0.08 * *$ & $-0.79 * * *$ & $-0.17 * * *$ & 1.00 \\
\hline X6a & $0.42 * * *$ & $0.24 * * *$ & -0.04 & $0.14 * * *$ & $0.15^{* * *}$ & $0.16^{* * *}$ & $-0.12 * * *$ & 0.00 & $-0.23 * * *$ & -0.02 & $0.27^{* * *}$ \\
\hline $\mathrm{X} 6 \mathrm{~b}$ & 0.04 & $-0.11 * * *$ & -0.04 & $0.14 * * *$ & $0.07^{*}$ & $0.13 * * *$ & -0.01 & $-0.12 * * *$ & $-0.14 * * *$ & $-0.06^{*}$ & $0.19 * * *$ \\
\hline $\mathrm{X} 7$ & $0.21 * * *$ & 0.05 & 0.01 & $0.23 * * *$ & $0.13^{* * *}$ & $0.22 * * *$ & $-0.08 * *$ & $-0.10 * * *$ & $-0.20 * * *$ & $-0.05^{*}$ & $0.16^{* * *}$ \\
\hline $\mathrm{X} 8$ & $-0.07 * * *$ & $-0.13 * * *$ & -0.01 & $-0.13 * * *$ & $-0.14 * * *$ & $0.07 * *$ & $0.39 * * *$ & $-0.88 * *$ & $0.49 * * *$ & $0.06^{*}$ & $-0.55 * * *$ \\
\hline $\mathrm{X} 10$ & $0.79 * * *$ & $0.25 * * *$ & $0.06^{*}$ & $0.26 * * *$ & $0.18^{* * *}$ & $0.24 * * *$ & $-0.08 * *$ & $-0.28 * * *$ & $-0.37 * * *$ & 0.00 & $0.39^{* * *}$ \\
\hline X11 & 0.02 & -0.05 & 0.03 & 0.02 & $0.06^{*}$ & $0.10 * * *$ & $-0.09 * *$ & -0.05 & $-0.07 * *$ & $-0.08 * *$ & $0.07 *$ \\
\hline $\mathrm{X} 12$ & 0.02 & 0.02 & 0.03 & 0.04 & 0.04 & 0.05 & -0.05 & $-0.15^{* * *}$ & $-0.06^{*}$ & -0.02 & $0.06^{*}$ \\
\hline $\mathrm{X} 13$ & $-0.17 * * *$ & $-0.07 * * *$ & -0.04 & -0.02 & $-0.08 * *$ & -0.01 & -0.05 & -0.05 & $0.07 * *$ & -0.04 & $-0.06^{*}$ \\
\hline X14 & $0.15^{* * *}$ & $0.09 * * *$ & 0.01 & -0.05 & -0.02 & $-0.07 *$ & 0.03 & $0.22 * * *$ & $-0.08 * *$ & 0.00 & $0.07^{* * *}$ \\
\hline \multirow[t]{2}{*}{$\mathrm{X} 15$} & $0.06^{*}$ & $0.09 * *$ & 0.00 & -0.01 & 0.04 & $-0.10 * * *$ & $-0.13^{* * *}$ & $0.11 * * *$ & $-0.15^{* * *}$ & $0.14 * * *$ & $0.12 * * *$ \\
\hline & X6a & X6b & $\mathrm{X} 7$ & X8 & & & X11 & X12 & X13 & X14 & X15 \\
\hline
\end{tabular}

\begin{tabular}{|c|c|c|c|c|c|c|c|c|c|c|}
\hline \multicolumn{11}{|l|}{$\mathrm{Y}$} \\
\hline \multicolumn{11}{|l|}{$\mathrm{X} 1 \mathrm{a}$} \\
\hline \multicolumn{11}{|l|}{$\mathrm{X} 1 \mathrm{~b}$} \\
\hline \multicolumn{11}{|l|}{$\mathrm{X} 1 \mathrm{c}$} \\
\hline \multicolumn{11}{|l|}{ X1d } \\
\hline \multicolumn{11}{|l|}{$\mathrm{X} 2$} \\
\hline \multicolumn{11}{|l|}{$\mathrm{X} 3$} \\
\hline \multicolumn{11}{|l|}{$\mathrm{X} 4$} \\
\hline \multicolumn{11}{|l|}{ X5a } \\
\hline \multicolumn{11}{|l|}{$\mathrm{X} 5 \mathrm{~b}$} \\
\hline \multicolumn{11}{|l|}{$\mathrm{X} 5 \mathrm{c}$} \\
\hline X6a & 1.00 & & & & & & & & & \\
\hline X6b & $-0.14 * * *$ & 1.00 & & & & & & & & \\
\hline X7 & $0.18^{* * *}$ & $0.10^{* * *}$ & 1.00 & & & & & & & \\
\hline $\mathrm{X} 8$ & $-0.23 * * *$ & 0.01 & $-0.13 * * *$ & 1.00 & & & & & & \\
\hline $\mathrm{X} 10$ & $0.45^{* * *}$ & $0.07 *$ & $0.32 * * *$ & $-0.10 * * *$ & 1.00 & & & & & \\
\hline X11 & $-0.12 * * *$ & $0.12 * * *$ & $0.18 * * *$ & -0.04 & $-0.07 * *$ & 1.00 & & & & \\
\hline $\mathrm{X} 12$ & 0.00 & $0.10^{* * *}$ & $0.12 * * *$ & 0.00 & 0.03 & 0.01 & 1.00 & & & \\
\hline $\mathrm{X} 13$ & $-0.18 * * *$ & $0.11 * * *$ & $-0.06^{*}$ & 0.04 & $-0.31 * * *$ & $0.36^{* * *}$ & $0.075^{* *}$ & 1.00 & & \\
\hline X14 & 0.03 & 0.05 & 0.03 & -0.05 & $0.10 * * *$ & $0.13 * * *$ & $-0.07 * *$ & 0.04 & 1.00 & \\
\hline $\mathrm{X} 15$ & $0.07 * *$ & $-0.10 * * *$ & $-0.07 * *$ & $-0.09 * *$ & $0.07 *$ & $-0.15 * * *$ & -0.04 & 0.01 & $0.09 * *$ & 1.00 \\
\hline
\end{tabular}

The variables are defined as : $\mathrm{Y}=$ Natural $\log$ of audit fees; $\mathrm{X} 1 \mathrm{a}=$ audit committee meeting frequency; $\mathrm{X} 1 \mathrm{~b}=$ Proportion of independent director in $\mathrm{AC} ; \mathrm{X} 1 \mathrm{c}=\mathrm{AC}$ size; $\mathrm{X} 1 \mathrm{~d}=$ proportion of non-executive directors in $\mathrm{AC}$; $\mathrm{X} 2=$ Percentage of block shareholder; $\mathrm{X} 3=\mathrm{CEO}$ and Chairman duality; $\mathrm{X} 4=$ Financial state; $\mathrm{X} 5 \mathrm{a}=$ Chinese 
dominance; $\mathrm{X} 5 \mathrm{~b}=$ Bumiputra dominance; $\mathrm{X} 5 \mathrm{c}=$ Institutional dominance; $\mathrm{X} 6 \mathrm{a}=$ Strong political connection; $\mathrm{X} 6 \mathrm{~b}=$ Weak political connection; $\mathrm{X} 7=$ Yearly closing share price; $\mathrm{X} 8=$ family - controlled firm; $\mathrm{X} 10=$ natural $\log$ of total assets; $\mathrm{X} 11=$ assets turnover; $\mathrm{X} 12=$ return on assets; $\mathrm{X} 13=$ current assets over total assets; $\mathrm{X} 14=$ total liabilities over total assets; $\mathrm{X} 15=$ beta.

*Significant at the $10 \%$ level ** Significant at the $5 \%$ level

*** Significant at the $1 \%$ level.

\subsection{Summary Statistics and Regression Results}

The regression results for the model are reported in Table 4 . The table reports the model $\mathrm{R}^{2}$ and adjusted $\mathrm{R}^{2}$ values to explain the explanatory power of the model. The $\mathrm{R}^{2}$ for the model was 0.68 in 2006, 0.67 in 2007, and 0.69 in 2008. According to Field (2009), $\mathrm{R}^{2}$ is a measure of how much of the variability in the outcome is accounted for by the predictors. This means that for example in 2006 the independent variables shared $67 \%$ of the variability in audit fee paid. With reference to the generated $\mathrm{R}^{2}$ and adjusted $\mathrm{R}^{2}$, the model had a consistent (if not better) adjusted $\mathrm{R}^{2}$ value with a number of researches in Malaysia with the same theme such as Gul (2006), Puan et al. (2006), Mark et al. (2007) and Effiezal Aswadi et al. (2009).

Furthermore, the model was expected to be able to predict the outcome variable based on the F-ratio where $\mathrm{F}=$ 29.50 in $2006, F=28.49$ in 2007 , and $F=31.05$ in 2008 which were all highly significant at $p<0.0001$. The multicollinearity assumptions were doubled checked for the model through a feature in SPSS to generate the Variance Inflation Factor (VIF) and tolerance statistics. For this model, the VIF values were well below 10 and the tolerance statistics were all well above 0.2 thus, it could safely be concluded that there was no collinearity within the data. For the purpose of hypotheses testing, only significant levels at $1 \%$ and $5 \%$ will be regarded as significant.

Table 4 also provides the regression results for the three years study period (pre-MCCG, 2007; transition to MCCG, 2007; and post-MCCG, 2007). The first column is the list of variables used. The second column is the predicted coefficient sign derived from the hypotheses. The first column in the year 2006 with ' $\mathrm{B}$ ' symbol is the b-values. According to Field (2009), individual contribution of each predictor in the model is indicated by the b-values. In other words, b-value indicates the relationship between a dependent and independent variable in the model tested. The second column in 2006 is standard error (SE B). Field (2009) mentioned that standard error indicates the extent the b-values "would vary across different sample, and these standard errors are used to determine whether or not the b-value differs significantly from zero" (p. 239). The third column in the year 2006 is the standardized beta (Beta). Standardized beta "tell us the number of standard deviations that the outcome will change as a result of one standard deviation change in the predictor" (p239). In other words, standardized beta is a scaled beta which is directly comparable to one another as to measure the important level of each predictor.

Table 4. OLS regression results

\begin{tabular}{|c|c|c|c|c|c|c|c|c|c|c|}
\hline & & 2006 & & 20 & & & 2008 & & & \\
\hline Prediction & & B & $S E B$ & Beta & B & $S E B$ & Beta & B & $S E B$ & Beta \\
\hline Constant & $?$ & 8.17 & 0.46 & & 7.84 & 0.46 & & 8.38 & 0.48 & \\
\hline $\mathrm{X} 1 \mathrm{a}$ & - & 0.01 & 0.03 & 0.01 & 0.07 & 0.03 & $0.08 * *$ & 0.04 & 0.03 & 0.04 \\
\hline $\mathrm{X} 1 \mathrm{~b}$ & - & -0.24 & 0.42 & -0.02 & 0.13 & 0.31 & 0.02 & 0.53 & 0.22 & $0.09 * *$ \\
\hline $\mathrm{X} 1 \mathrm{c}$ & - & 0.03 & 0.06 & 0.02 & 0.01 & 0.06 & 0.01 & 0.00 & 0.06 & 0.00 \\
\hline X1d & - & -0.27 & 0.32 & -0.04 & 0.11 & 0.29 & 0.02 & -0.45 & 0.32 & -0.05 \\
\hline $\mathrm{X} 2$ & + & -0.86 & 0.25 & $-0.13 * * *$ & -0.96 & 0.25 & $-0.15^{* * *}$ & -1.01 & 0.25 & $-0.15 * * *$ \\
\hline $\mathrm{X} 3$ & + & 0.18 & 0.09 & $0.08 * *$ & 0.16 & 0.08 & $0.07 *$ & 0.03 & 0.08 & 0.01 \\
\hline $\mathrm{X} 4$ & + & 0.09 & 0.11 & 0.03 & 0.00 & 0.11 & 0.00 & 0.16 & 0.10 & 0.07 \\
\hline X5a & $?$ & 0.03 & 0.21 & 0.02 & 0.14 & 0.20 & 0.06 & 0.02 & 0.18 & 0.01 \\
\hline $\mathrm{X} 5 \mathrm{~b}$ & $?$ & 0.12 & 0.26 & 0.03 & 0.34 & 0.24 & 0.08 & 0.17 & 0.22 & 0.04 \\
\hline $\mathrm{X} 5 \mathrm{c}$ & $?$ & 0.24 & 0.22 & 0.10 & 0.43 & 0.21 & $0.19^{* *}$ & 0.37 & 0.20 & $0.16^{*}$ \\
\hline X6a & + & 0.27 & 0.13 & $0.09 * *$ & 0.40 & 0.13 & $0.13^{* * *}$ & 0.41 & 0.12 & $0.13^{* * *}$ \\
\hline X6b & + & -0.12 & 0.13 & 0.04 & -0.02 & 0.12 & -0.01 & 0.11 & 0.12 & 0.03 \\
\hline
\end{tabular}




\begin{tabular}{|c|c|c|c|c|c|c|c|c|c|c|}
\hline & & 2006 & & & & & 2008 & & & \\
\hline Prediction & & B & $S E B$ & Beta & B & $S E B$ & Beta & B & $S E B$ & Beta \\
\hline $\mathrm{X} 7$ & $?$ & -0.01 & 0.01 & -0.03 & -0.01 & 0.01 & -0.02 & -0.02 & 0.01 & -0.06 \\
\hline X8 & + & 0.12 & 0.10 & 0.06 & 0.20 & 0.10 & $0.09 * *$ & 0.23 & 0.10 & $0.11^{* *}$ \\
\hline $\mathrm{X} 10$ & $?$ & 0.60 & 0.04 & $0.81 * * *$ & 0.52 & 0.04 & $0.72 * * *$ & 0.52 & 0.03 & $0.75 * * *$ \\
\hline X11 & $?$ & 0.15 & 0.07 & $0.09 * *$ & 0.17 & 0.07 & $0.10 * *$ & 0.06 & 0.05 & 0.04 \\
\hline $\mathrm{X} 12$ & $?$ & 0.00 & 0.01 & 0.03 & 0.00 & 0.00 & -0.02 & 0.01 & 0.00 & $0.08 *$ \\
\hline $\mathrm{X} 13$ & $?$ & 0.41 & 0.22 & $0.08^{*}$ & 0.27 & 0.21 & 0.05 & 0.35 & 0.21 & $0.06^{*}$ \\
\hline X14 & $?$ & 0.16 & 0.13 & 0.07 & 0.30 & 0.21 & 0.06 & 0.25 & 0.18 & 0.05 \\
\hline $\mathrm{X} 15$ & $?$ & 0.00 & 0.05 & 0.00 & -0.03 & 0.05 & -0.02 & -0.03 & 0.04 & -0.02 \\
\hline $\mathrm{R}^{2}$ & & & 0.68 & & & 0.67 & & & 0.69 & \\
\hline Adjusted $\mathrm{R}^{2}$ & & & 0.66 & & & 0.65 & & & 0.67 & \\
\hline $\mathrm{P}$-value of $F$-test & & $<0.0001$ & & & $<0.0001$ & & & $<0.0001$ & & \\
\hline
\end{tabular}

The variables are defined as : $\mathrm{Y}=$ Natural $\log$ of audit fees; $\mathrm{X} 1 \mathrm{a}=$ audit committee meeting frequency; $\mathrm{X} 1 \mathrm{~b}=$ Proportion of independent director in $\mathrm{AC} ; \mathrm{X} 1 \mathrm{c}=\mathrm{AC}$ size; $\mathrm{X} 1 \mathrm{~d}=$ proportion of non-executive directors in $\mathrm{AC}$; $\mathrm{X} 2=$ Percentage of block shareholder; $\mathrm{X} 3=\mathrm{CEO}$ and Chairman duality; $\mathrm{X} 4=$ Financial state; $\mathrm{X} 5 \mathrm{a}=$ Chinese dominance; $\mathrm{X} 5 \mathrm{~b}=$ Bumiputra dominance; $\mathrm{X} 5 \mathrm{c}=$ Institutional dominance; $\mathrm{X} 6 \mathrm{a}=$ Strong political connection; $\mathrm{X} 6 \mathrm{~b}=$ Weak political connection; $\mathrm{X} 7=$ Yearly closing share price; $\mathrm{X} 8=$ family -controlled firm; $\mathrm{X} 10=$ natural $\log$ of total assets; $\mathrm{X} 11=$ assets turnover; $\mathrm{X} 12=$ return on assets; $\mathrm{X} 13=$ current assets over total assets; $\mathrm{X} 14=$ total liabilities over total assets; X15= beta.

$*$ Significant at the $10 \%$ level $\quad * *$ Significant at the $5 \%$ level $\quad * * *$ Significant at the $1 \%$ level

Based on table, it could be seen that the AC meeting frequency was only significant at the $5 \%$ in 2007 (Beta $=0.08, \mathrm{p}<.05$ ). However, for both 2006 and 2008, X1a did not have any significant relationship with the amount of audit fee. Even though X1a in 2007 was significant at the $5 \%$ level, its coefficient deviated from the hypothesis which predicted the opposite effect. Thus, H1a was not supported.

The proportion independent directors in AC only showed a significant relationship at $5 \%$ in the year 2008 $(B e t a=0.09, p<.05$ ). Both 2006 and 2007 did not show any significant relationship (2006: Beta $=-0.02, p>.05$; 2007: Beta $=0.02, p>.05$ ). The coefficient of $\mathrm{X} 1 \mathrm{~b}$ was in the opposite direction with the predicted sign. Thus, $\mathrm{H} 1 \mathrm{~b}$ was not supported.

$\mathrm{AC}$ size (X1c) meanwhile did not show any significant relationship with the audit fee in all the three years period (2006: Beta $=0.02, p>.05 ; 2007$ : Beta $=0.01, p>.05 ; 2008$ : $B e t a=0.00, p>.05$ ). Thus, H1c was not supported

The similar results could also be seen in the proportion of the non-executive directors (X1d) variable whereby none of the years tested contained statistically significant relationship between X1d and audit fee (2006: Beta= $-0.04 p>.05 ; 2007$ : Beta $=0.02, p>.05 ; 2008$ : Beta $=-0.05, p>.05$ ). Thus, H1d was also not supported. Based on all of these results, it can be concluded that $\mathrm{H} 1$ is not supported for all the years of observation.

The size of the block shareholder is determined by the proportion of shares held by the largest, single shareholder in an entity. As shown in Table, the size of block shareholder had a significant relationship with natural $\log$ of audit fee at $1 \%$ level for all the three years observed (2006: Beta $=-0.13, p<0.01 ; 2007$ : Beta $-0.15, \mathrm{p}<.01 ; 2008$ : Beta $=-0.15, \mathrm{p}<.01)$. However, the coefficient results showed the opposite direction from the predicted sign based on the hypotheses developed. Thus, $\mathrm{H} 2$ was rejected.

$\mathrm{CEO}$ and chairman duality is the practice whereby the CEO of the company also holds the position as a chairman of the board. Based on Table, CEO and chairman duality had a positive significant relationship with natural log of audit fee at the 5\% level in 2006 (Beta $=0.08, \mathrm{p}<.05$ ). Furthermore in 2007, CEO duality had a significant relationship with natural $\log$ of audit fee at the $10 \%$ level (Beta=0.07. $\mathrm{p}<.10)$. However, in 2008 CEO and chairman duality did not have any significant relationship with natural audit fee (Beta $=0.01, p>.05$ ). Since this study accepted a significant level below than 5\% level, H3 was only supported in 2006.

Based on Table, the financial state of an entity did not have any significant relationship with natural log of audit fee for all the years observed (2006: Beta $=0.03, \mathrm{p}>.05 ; 2007$ : Beta $=0.00, \mathrm{p}>.05 ; 2008$ : Beta $=0.07, \mathrm{p}>.05$ ). For such reason, $\mathrm{H} 4$ was not supported.

As mentioned earlier, in ownership dominance consisted of three sub variables which were dichotomous; 
Chinese dominance, Bumiputra dominance, and institutional dominance. As shown in Table, Chinese dominance had no significant relationship with audit fee for all the years observed $(2006$ : Beta $=0.02, p>.05 ; 2007$ : Beta $=0.06, p>.05 ; 2008$ : Beta $=0.01, p>.05$ ). Similar results were also shown for Bumiputra dominance which had no significant relationship with audit fee (2006: Beta $=0.03, p>.05 ; 2007$ : Beta $=0.08, p>.05 ; 2006$ : Beta $=0.04$, $\mathrm{p}>.05$ ). However, institutional dominance showed a significant relationship at 5\% level in 2007 (Beta $=0.19$, $\mathrm{p}<.05$ ) and at $10 \%$ level in 2008 (Beta $=0.16, \mathrm{p}<.10$ ). Thus, it can be concluded that $\mathrm{H} 5$ was only supported in 2007 and rejected in both 2006 and 2008.

Political connection variable, consisted of two subs dichotomous variables; strong political connection and weak political connection. Both of the variables were aimed to denote the political connection strength of an entity. The regression results in Table confirmed that a strong political connection firm did have a positive significant relationship with audit fee in all the years observed (2006: Beta $=0.09, \mathrm{p}<.05 ; 2007$ : Beta $=0.13, \mathrm{p}<.01 ; 2008$ : $\mathrm{Beta}=0.13, \mathrm{p}<.01)$. Strong political connection was significant at $5 \%$ level in 2006 and at $1 \%$ level for both 2007 and 2008. Weak political connection however did not have any significant relationship with audit fee in all the yeas observed (2006: Beta $=-0.04, \mathrm{p}>.05 ; 2007$ : Beta $=-0.01, \mathrm{p}>.05 ; 2008$ : Beta $=0.03, \mathrm{p}>.05)$. Based on the results, it can be concluded that $\mathrm{H} 6$ was supported in all the three years.

As depicted in Table, the yearly closing share price was found not to have a significant relationship with audit fee in all the years observed (2006: Beta $=-0.03, \mathrm{p}>.05 ; 2007$ : Beta $=-0.02, \mathrm{p}>.05 ; 2008$ : Beta $=-0.06, \mathrm{p}>.05$ ). Based on such results, it can be concluded that $\mathrm{H} 7$ was not supported.

The family-controlled firms variable was reported to have a significant positive relationship with the natural $\log$ of audit fee at 5\% significant level in the year 2007 (Beta $=0.09, \mathrm{p}<.05)$ and 2008 (Beta $=0.11, \mathrm{p}<.05$ ). In 2006 however, there was no significant relationship identified. Based on the report, it can be safe to conclude that $\mathrm{H} 8$ was supported in both 2007 and 2008 and rejected in 2006.

Table 5. Summary of results of hypotheses tested

\begin{tabular}{cccc}
\hline Hypothesis & 2006 (Pre-MCCG 2007) & 2007 (Transition to MCCG 2007) & 2008 (Post MCCG 2007) \\
\hline H1 & Not supported & Not supported & Not supported \\
H2 & Not supported & Not supported & Not supported \\
H3 & Supported & Not supported & Not supported \\
H4 & Not supported & Not supported & Not supported \\
H5 & Not supported & Supported & Not supported \\
H6 & Supported & Supported & Supported \\
H7 & Not supported & Not supported & Not supported \\
H8 & Not supported & Supported & Supported \\
\hline
\end{tabular}

\subsection{Control Variables Tested in Model}

The selection of control variables in model was mainly based on the extensive past literature such of Waresul \& Moizer (1996), Sandra \& Patrick (1993), Kamal \& Rana (2008), Mark et al. (2007) and also an adaptation from the study of Lin \& Liu (2009).

It is worth to report that two control variables were identified to have a significant relationship with audit fee, consistent with past studies at international level. The first control variable was natural log of total assets which had a significant level of $1 \%$ in all the years observed (2006: Beta $=0.81, \mathrm{p}<.01 ; 2007$ : Beta $=0.72, \mathrm{p}<.01 ; 2008$ : $\mathrm{Beta}=0.75, \mathrm{p}<.01)$. The second variable was asset turnover which had a significant level at $5 \%$ in both the years $2006($ Beta $=0.09, \mathrm{p}<.05)$ and $2007($ Beta $=0.10, \mathrm{p}<0.05)$.

\section{Discussion}

\subsection{Audit Fee Determinants in 2006 (Prior to MCCG 2007)}

This study found that the larger the block shareholder, the lower was the audit fee. This finding was actually in the opposite direction from the initial hypothesis whereby a higher audit fee was expected when a large block shareholder was in control. The initial hypothesis expected that a large block shareholder is assumed to have weaker governance through power concentration and have more incentive to expropriate the minority 
shareholder's wealth. Yet, the finding of this study proves otherwise. This finding is actually similar with the results of a study in the UK by Zaman, Hudaib \& Haniffa (2011) whereby large shareholders were expected to have a negative relationship with audit fee and NAS fee. Zaman et al. (2011) mentioned that a more diffused ownership relied more heavily to an external audit. However, the authors suggested that large shareholders may employ different methods of monitoring instead of just relying heavily on the audit, thus the reason why large shareholders may put less demand on an audit effort (subsequently lowering audit fee). This finding is however inconsistent with the view of Guy, Ahmed and Randal (2010) and Gul, Kim and Qiu (2010) who suggested that companies with a high concentration of ownership demand for a high quality audit to signal better CG.

The notion that the CEO and chairman duality is related to higher audit fee is supported in this study. This finding is consistent with that of Mark et al. (2007) who also conducted a study on the Malaysian PLCs in 2001. Past studies associated CEO duality with weak governance. Since weak governance creates loopholes for fraud, manipulations and incentives to be pursued for personal interests especially by the CEO, it is associated with higher business risk. CEO duality is normal among family-controlled firms where power and ownership usually circulate among family members.

The same argument (on level of riskiness) could also be used in explaining the relationship between the firms' higher audit fee with the politically-connected firms. Politically-connected firms are perceived to bear higher inherent risks due to higher possibility of business failures and misstatements of financial information to avoid covenant violation. This assertion has actually been tested and confirmed by Effiezal Aswadi et al. (2009).

As expected, based on the control variables, an entity with larger size and higher level of growth attracted higher audit fee. The audit effort is more thorough for larger sized firms which consumed more audit resources causing audit fee to be higher. Faster growing firms on the other hand, may involve a more sophisticated and complex transaction. This requires some level of expertise during the external audit, also causing higher audit fee. This indicated that the size and growth level of an entity were still considered as important determinants of audit fee by auditors during the pre-MCCG 2007 period which was consistent with the classical determination of the audit fee.

\subsection{Audit Fee Determinants in 2008 (Post MCCG 2007)}

This study found that after the introduction of MCCG2007, largest shareholder block and strong political connection variables were still the determinants of audit fee. However, two new variables (proportion of independent directors and family-controlled firms) emerged as significant in post-MCCG 2007 while one explanatory variable (CEO Duality) from pre-MCCG 2007 was no longer significant. Based on the regression results, the proportion of independent director in the $\mathrm{AC}$ was found to have a positive significant relationship with audit fee after the introduction of MCCG 2007. This finding, even though significant, deviated from the initial hypothesis which predicted a negative relationship due to the lower level of risk whenever a larger proportion of independent director existed within the AC. It is worth noting that the independent director most of the time is a non-executive. But, non-executive directors are not necessarily independent. Since MCCG 2007 required the $\mathrm{AC}$ members to be fully comprised by non-executives, there was a big reform in the AC structure.

Independent non-executive directors, different from non-independent directors are more objective and unbiased. They may demand higher quality audit and more audit effort in order to reduce the probability of fraud, misstatement, manipulation and earning management. This incentive may cause the audit fee to be higher for companies with larger size of independent director as suggested by the results of this study. This argument is plausible since a study in the UK market by Zaman et al. (2011) also suggested and agreed with such notion. The authors suggested that independent non-executive directors within the AC had the power to overrule the management in demanding more audit effort to ensure its quality.

This study supported the notion that family-controlled firms were positively related to audit fee. The usual explanation could be found in the previous section which argued that due to the inherently poor governance in family-controlled firms, these firms tended to hire high quality auditors to improve their governance without jeopardizing their power and ownership. This will eventually cause a higher audit fee. However, such explanation does not answer the question on why the family-controlled firm variable was only significantly related to audit fee after the introduction of MCCG 2007 (year 2008).

The most plausible explanation is that the introduction of MCCG 2007 had forced family-controlled firms to revise their AC structure further. It is safe to say that family-controlled firms, most of the time included family members (who are non-independent executive directors) as a member of the AC. As argued earlier, the employment of non-executive directors in the AC may also suggest an increase in the employment of independent directors in the AC. Thus, based on the earlier discussion, this would cause audit fee to be higher 
(due to more demand on audit effort). In this case, MCCG 2007 had indirectly pushed family-controlled firms to employ more independent non-executive directors causing audit fee to be higher for family-controlled firms.

After the introduction of MCCG 2007, the CEO duality variable was no longer significantly related to audit fee. This may have been related to the earlier discussion on the increasing trend in the employment of independent directors within the AC after the introduction of MCCG 2007 among family-controlled firms. Mark et al. (2007) tested the effect of interaction between CEO duality and proportion of independent directors in the AC with audit fee.Based on their study, audit fee tended to be lower for companieswhich practiced CEO duality whenever they employed more independent directors on the AC. This was due to the increase in monitoring effectiveness whenever there were independent directors. The authors also suggested that the auditor's perceived riskiness on companies with CEO duality deminished with an inrcease in independent directors on the AC.In a nutshell, the plausible reason that the $\mathrm{CEO}$ and chairman duality variable was no longer significant after the introduction of MCCG 2007 was due to the 'set-off' effect through the employment of an independent director. This has set-off the auditor's perceived riskiness onCEO duality practices especially in family-controlled firms.

\section{Conclusion}

This study investigates the relationship of the firms' internal corporate governance mechanism with audit fee paid up in Malaysia. We find that only ownership concentration and political connection that give significant impact to the audit fees in all three years of observation-2006, 2007 and 2008. The proportion of independent directors in AC is significant in 2008, after the MCCG 2007 whereby CEO duality is only significant in 2006, before the MCCG 2007. Audit committee meetings frequency and institutional ownership dominance is significant during the transition of MCCG2007. Finally, family controlled firm is significant during the transition and after the MCCG 2007.

We also finds that overall, audit fee did not decrease. One of the reasons possibly due to the employment of more independent non-executive directors in the AC creating more demands for the audit effort to improve its quality. Thus, more action taken to improve the audit structure of the company internally as compared to depending the external audit firm to advise and strengthen the internal control of the company.

Based on the overall results of this study and the assessment of the MCCG2007 recommendations, it could be concluded that the new MCCG 2007 had improved the CG of PLCs especially those with inherently higher risks. The introduction of MCCG 2007 had reduced information asymmetry substantially through a more independent, more financial literate $\mathrm{AC}$ members as well as with continuous engagement between the chairman of the AC, senior management and external auditors. In addition, the self-serving behaviour among powerful members of the organization was monitored closely with a more independent $\mathrm{AC}$ and increase in the frequency of meetings between the $\mathrm{AC}$ and external auditor. Thus, audit risks in general was substantially reduced with the reduction in information asymmetry, closely monitored self-serving behavior and the introduction of internal audit function in every company.

There were a few limitations that may have impeded the precision of this study. First, in regards to the anchor of this study, it was also anchored by a research done in China. However, the results of this study revealed that the behavior of the Malaysian market was more identical to a more developed market such as the UK causing a few of the results to deviate in the opposite direction even though they were significant. Second, this study did not take into consideration the $\mathrm{AC}$ expertise. The inclusion of the $\mathrm{AC}$ expertise into the $\mathrm{AC}$ composition and operation may further give corroboration into the important roles of the $\mathrm{AC}$ composition with the introduction of MCCG 2007.

It suggested that a future study could evaluate the impact of MCCG 2007 in a more specific and detailed manner. The data suggested are to be in a longer longitudinal time frame so that solid evidence could be found. Incorporation of qualitative data such as interviews and surveys may increase the value of this study. Since the research regarding MCCG 2007 is still considered to be limited, there is still abundance of research opportunities available to be explored in this area.

\section{References}

Abbott, L., Gunny, K., \& Zhang, T. C. (2013). When the PCAOB talks, who listens? Evidence from client firm reaction to GAAP-deficient PCAOB inspection reports of small auditors. Auditing: A Journal of Practice \& Theory, 32(2), 1-31. http://dx.doi.org/10.2308/ajpt-50374

Al-Ajmi, J. (2008). Audit and reporting delays: Evidence from an emerging market. Advances in Accounting, 24(2), 217-226. http://dx.doi.org/10.1016/j.adiac.2008.08.002

Asthana, S. C., \& Boone, J. P. (2012). Abnormal audit fee and audit quality. AUDITING: A Journal of Practice 
\& Theory, 31(3), 1-22. http://dx.doi.org/10.2308/ajpt-10294

Aswadi, A. W. E., Mazlina, M. Z., Kieran, J., \& Hasnah, H. (2009). Institutional investors, political connection and audit quality in Malaysia. Accounting Research Journal, 22(2), 167-195. http://dx.doi.org/10.1108/10309610910987501

Badertscher, B., Jorgensen, B., Katz, S., \& Kinney, W. (2013). Litigation risk and audit pricing: The role of public equity. http://dx.doi.org/10.2139/ssrn.2196253

Beck, A. K., Fuller, R., Muriel, L. E., \& Reid, C. D. (2013). Audit Fees and Investor Perceptions of Audit Characteristics (Formerly: The Effect of Audit Fee Magnitude on Investor Perceptions of Audit Quality and Independence). Behavioral Research in Accounting (in Press). http://dx.doi.org/10.2308/bria-50403

Burkart, M., \& Panunzi, F. (2006). Agency conflicts, ownership concentration, and legal shareholder protection. Journal of Financial Intermediation, 15(1), 1-31. http://dx.doi.org/10.1016/j.jfi.2004.12.004

Casterella, J. R., Desir, R., \& Irwin, G. (2013). A retrospective look at the effect of auditor specialization and industry concentration on the cost of audit services. Accounting and Finance Research, 2(2), 79-88. http://dx.doi.org/10.5430/afr.v2n2p79

Cheung, Y. L., Stouraitis, A., \& Wong, A. W. S. (2005). Ownership concentration and executive compensation in closely held firms: Evidence from Hong Kong. Journal of Empirical Finance, 12(4), 511-532. http://dx.doi.org/10.1016/j.jempfin.2004.10.001

Cohen, S., \& Leventis, S. (2013). An empirical investigation of audit pricing in the public sector: The case of Greek LGOs. Financial Accountability \& Management, 29(1), 74-98. http://dx.doi.org/10.1111/faam.12003

Coster, D. C., Dahl, D., \& Jenson, R. L. (2013). Modeling linear trends in audit fees. International Journal of Auditing (in Press). http://dx.doi.org/10.1111/ijau.12012

DeAngelo, L. E. (1981). Auditor size and audit quality. Journal of Accounting and Economics, 3(3), 183-199. http://dx.doi.org/10.1016/0165-4101(81)90002-1

Ebrahim, A. (2010). Audit fee premium and auditor change: the effect of Sarbanes-Oxley Act. Managerial Auditing Journal, 25(2), 102-121. http://dx.doi.org/10.1108/02686901011008936

Field, A. (2009). Discovering Statistics Using SPSS (3rd ed.). London: SAGE Publication Ltd.

Gul, F. A. (2006). Auditors' response to political connections and cronyism in Malaysia. Journal of Accounting Research, 44(5), 931-963. http://dx.doi.org/10.1111/j.1475-679X.2006.00220.x

Gul, F. A., Kim, J. B., \& Qiu, A. A. (2010). Ownership concentration, foreign shareholding, audit quality, and stock price synchronicity: Evidence from China. Journal of Financial Economics, 95(3), 425-442. http://dx.doi.org/10.1016/j.jfineco.2009.11.005

Guy, D. F., Ahmed, M. A. M., \& Randal, J. E. (2010). Audit quality attributes, client size and cost of equity capital. Review of Accounting and Finance, 9(4), 363-381. http://dx.doi.org/10.1108/14757701011094571

Haiyan, J., Ahsan, H., \& Clive, S. (2009). The effect of ownership concentration on CEO compensation-firm performance relationship in New Zealand. Pacific Accounting Review, 21(2), 104-131. http://dx.doi.org/10.1108/01140580911002053

Kamal, N., \& Rana, N. (2008). Determinants of audit fees: empirical evidence from an emerging economy. International Journal of Commerce and Management, 17(3), 239-254. http://dx.doi.org/10.1108/10569210710833635

Kane, G. D., \& Velury, U. (2004). The role of institutional ownership in the market for auditing services: an empirical investigation. Journal of Business Research, 57(9), 976-983. http://dx.doi.org/10.1016/S0148-2963(02)00499-X

Kim, H., \& Fukukawa, H. (2012). Japan's big 3 firms' response to clients' business risk: Greater audit effort or higher audit fees? International Journal of Auditing, 17(2), 190-212. http://dx.doi.org/10.1111/j.1099-1123.2012.00464.x

Kim, K. H., Al-Shammari, H. A., Kim, B., \& Lee, S. H. (2009). CEO duality leadership and corporate diversification behavior. Journal of Business Research, 62(11), 1173-1180. http://dx.doi.org/10.1016/j.jbusres.2008.10.017

Krauß, P., Quosigk, B. M., \& Zülch, H. (2013). Effects of Initial Audit Fee Discounts on Audit Quality: Evidence from Germany. International Journal of Auditing (in Press). http://dx.doi.org/10.1111/ijau.12010

La, P. R., Florencio, L. D. S., \& Andrei, S. (1999). Corporate ownership around the world. The Journal of Finance, 54(2), 471. http://dx.doi.org/10.1111/0022-1082.00115

Leuz, C., \& Verrecchia, R. E. (2000). The economic consequences of increased disclosure. Journal of 
Accounting Research, 38, 91-124. http://dx.doi.org/10.2307/2672910

Leventis, S., Hasan, I., \& Dedoulis, E. (2013). The cost of sin: The effect of social norms on audit pricing. International Review of Financial Analysis (in Press). http://dx.doi.org/10.1016/j.irfa.2013.03.006

Lin, Z. J., \& Liu, M. (2009). The impact of corporate governance on auditor choice: Evidence from China. Journal of International Accounting, Auditing and Taxation, 18(1), 44-59. http://dx.doi.org/10.1016/j.intaccaudtax.2008.12.005

Mark, A. B., Balachandran, M., \& Abdul, M. (2007). CEO duality, audit committee effectiveness and audit risks: A study of the Malaysian market. Managerial Auditing Journal, 22(7), 716-728. http://dx.doi.org/10.1108/02686900710772609

Mary, F. A., Mark, L., \& David, M. S. (2005). The effect of litigation on independent auditor selection. American Journal of Business, 20(1), 37-45. http://dx.doi.org/10.1108/19355181200500004

Mitton, T. (2002). A cross-firm analysis of the impact of corporate governance on the East Asian financial crisis. Journal of Financial Economics, 64(2), 215-241. http://dx.doi.org/10.1016/S0304-405X(02)00076-4

Mohd, M. R., \& Takiah, M. I. (1993). Audit fee premiums from brand name, industry specialization and industry leadership: A study of the post Big 6 merger in Malaysia. Asian Review of Accounting, 12(2), 1-24. http://dx.doi.org/10.1108/eb060775

Prawitt, D. F., Sharp, N. Y., \& Wood, D. A. (2011). Reconciling archival and experimental research: Does internal audit contribution affect the external audit fee? Behavioral Research in Accounting, 23(2), 187-206. http://dx.doi.org/10.2308/bria-10065

Puan, Y., Pamela, K., \& Peter, C. (2006). Governance structures, ethnicity, and audit fees of Malaysian listed firms. Managerial Auditing Journal, 21(7), 757-782. http://dx.doi.org/10.1108/02686900610680530

Sandra, W. M. H., \& Patrick, P. H. N. (1993). The deteminants of audit fees in HongKong: An empirical study. Asian Review of Accounting, 4(2), 32-50. http://dx.doi.org/10.1108/eb060673

Sawicki, J. (2009). Corporate governance and dividend policy in Southeast Asia pre- and post-crisis. The European Journal of Finance, 15(2), 211-230. http://dx.doi.org/10.1080/13518470802604440

Simon, D. T. (2011). Additional evidence on the large audit-firm fee premium as an indication of auditor quality. Journal of Applied Business Research, 13(4), 21-30.

Sundgren, S., \& Svanström, T. (2013). Audit office size, audit quality and audit pricing: evidence from small-and medium-sized enterprises. Accounting and Business Research, 43(1), 31-55. http://dx.doi.org/10.1080/00014788.2012.691710

Taylor, M. H., \& Simon, D. T. (1999). Determinants of audit fees: the importance of litigation, disclosure, and regulatory burdens in audit engagements in 20 countries. The International Journal of Accounting, 34(3), 375-388. http://dx.doi.org/10.1016/S0020-7063(99)00017-5

Wahab, E. A. A., \& Zain, M. M. (2013). Audit fees during initial engagement in Malaysia. Managerial Auditing Journal, 28(8). http://dx.doi.org/10.1108/MAJ-Sep-2012-0752

Waresul, K. A. K. M., \& Moizer, P. (1996). Determinants of audit fees in Bangladesh. The International Journal of Accounting, 31(4), 497-509. http://dx.doi.org/10.1016/S0020-7063(96)90034-5

Zaman, M., Hudaib, M., \& Haniffa, R. (2011). Corporate governance quality, audit fees and non-audit services. Journal of Business Finance and Accounting, 38(1), 165-197. http://dx.doi.org/10.1111/j.1468-5957.2010.02224.x

\section{Copyrights}

Copyright for this article is retained by the author(s), with first publication rights granted to the journal.

This is an open-access article distributed under the terms and conditions of the Creative Commons Attribution license (http://creativecommons.org/licenses/by/3.0/). 